\title{
Changes in the Cytoplasmic Androgen Receptor of Rat Ventral Prostate after Administration of Androgens, Antiandrogens and Anabolic Steroids
}

\author{
SHogo ICHII \\ Division of Physiology, Institute of Steroid Research, \\ Tottori University School of Medicine, \\ Yonago 683, Japan
}

\begin{abstract}
The effect of the administration of androgens (testosterone and dihydrotestosterone ${ }^{*}$ ), antiandrogens (progesterone and cyproterone acetate) and anabolic steroids (Bolandiol, Nandrolone, Furazabol and Methenolone) on depletion and replenishment of the androgen receptor in the cytosol of ventral prostate from castrated rats was examined using ${ }^{3} \mathrm{H}$-R 1881 as the ligand. Administration of androgens lead to a rapid fall in the level of the receptor and the receptor in the cytosol was replenished in the period following treatment. Length of the period of receptor depletion was dependent on the dose of androgen administered. Administration of antiandrogens did not cause any depletion of the receptor and concomitant administration of testosterone induced a pattern similar to that of the depletion observed following administration of testosterone alone. Effect of pretreatment of animals with ethidium bromide, an intercalating dye which has been shown to prevent the in vitro nuclear binding of steroid hormone-receptor complexes, on the depletion of receptor induced by testosterone administration was also insignificant. Anabolic steroids depleted the receptor but the degree of depletion was relatively low. The rate of inhibition of in vitro ${ }^{3} \mathrm{H}-\mathrm{R} 1881$ binding by these anabolic steroids was not correlated to the rate of in vivo depletion of the receptor. The significance of these observations is discussed.
\end{abstract}

The translocation of steroid hormonecytoplasmic receptor complexes into nuclei has been though to be an indispensable step in the cellular mechanism of steroid hormone action. The administration of progesterone (Isomaa et al., 1978, Luu Tai et al. 1975, Mester and Baulieu, 1977, Batra, 1979) and estrogens (Mester and Baulieu, 1975, Korach and Ford, 1978) lead to a rapid fall in the concentration of the respective receptors in the cytosol and an increase in the nuclear

Received January 29, 1980.

* Trivial names used: R1881; $17 \beta$-hydroxy-17 $\alpha$ methyl-4, 9, 11-estratrien-3-one, dihydrotestosterone; $17 \beta$-hydroxy-5 $\alpha$-androstane-3-one, cyproterone acetate; 6-chloro- $1 \beta, 2 \beta$-dihydro-17 $\alpha$-hydroxy-3'-H-cyclopropa $[1,2]$ pregna-1, 4, 6-triene3, 20-dione-17-acetate, ethidium bromide; 3, 8diamino-5-ethyl-6-phenylphenanthridinium bro- compartment. The depletion of cytoplasmic receptors after administration of the steroid hormones has been regarded as a consequence of nuclear translocation of the steroid hormone-receptor complexes. However, Mester and Baulieu (1977) and Horwitz and McGuire (1978) stated that the increase in the nuclear receptor was too little to account for the reduction in the cytosolic receptors after hormone administration. Van Doorn and Bruchovsky (1978) reached the

mide, Bolandiol dipropionate; 19-nor-4-androstene-3 $\beta, 17 \beta$-diol-3, 17-dipropionate, Nandrolone phenylpropionate; 19-nor-testosterone phenylpropionate, Furazabol; $17 \beta$-hydroxy-17 $\alpha$-methyl-5 $\alpha$ androstano $[2,3-C]$-furazan, Methenolone enanthate ; $17 \beta$-hydroxy-1-methyl-1-androstene-3-oneenanthate. 
conclusion that nuclear receptors originate exclusively through the translocation of the cytoplasmic receptor in rat prostate after the administration of androgens. while, Jungblut et al. (1978) and Panko and MacLeod (1978) reported the presence of steroid-free "activated" estrogen receptors in nuclei of pig uterus and human breast cancer.

Differences in the pattern of depletion and replenishment of the cytoplasmic receptors after the administration of estrogens and antiestrogens were reported by several investigators (Clark et al., 1973, Kazenellenbogen and Ferguson, 1975, Cildowski and Muldoon, 1976). Antiestrogens were bound to cytoplasmic estrogen receptor, then translocated to nuclei but consequent replenishment of the receptor in cytoplasm did not take place. The failure to cause replenishment of cytoplasmic estrogen receptor has been considered as an essential feature of antiestrogenic action, but in studies by Koseki et al. (1977) and Baudendistel et al. (1978), the pattern of depletion and replenishment of cytoplasmic receptor after the administration of estrogens was almost identical to that after the administration of antiestrogens.

As mentioned above, although a number of investigations have been carried out, the mechanism and physiological significance of translocation, depletion and replenishment of cytoplasmic receptors after administration of hormones in the steroid hormone action have not been fully elucidated.

In the present study, changes in the binding capacity of cytosols to ${ }^{3} \mathrm{H}-\mathrm{R} 1881$ in rat ventral prostate after the administration of androgens, antiandrogens and anabolic steroids were determined as a clue to the significance of depletion and replenishment of cytoplasmic androgen receptor in the androgenic action of steroid hormones.

\section{Materials and Methods}

\section{Animals and tissue preparations}

Male Wistar rats weighing $340-350 \mathrm{~g}$ were castrated via the scrotal route under ether anesthesia and used for experiments $48 \mathrm{hr}$ after operation. For the administration of steroids, steroids were dissolved or suspended in a $30 \%$ ethanol-saline solution and injected subcutaneously. Ventral prostates were homogenized in ice-cold buffer solution which consisted of $10 \mathrm{~mm}$ Tris- $\mathrm{HCl}(\mathrm{pH} 7.5), 2 \mathrm{~mm} 2$-mercaptoethanol and $0.5 \mathrm{~mm}$ EDTA. The homogenates were centrifuged at $100,000 \times g$ for $1 \mathrm{hr}$ and the resulting clear supernatants were referred to as the cytosols. In every experiment, tissues from at least 2 rats were combined and processed simultaneously. The volume of the homogenizing buffer solution was adjusted so as to make the concentration of protein in cytosols approximately $10 \mathrm{mg}$ per $\mathrm{ml}$.

\section{Isotopes and other chemicals}

${ }^{3} \mathrm{H}$-labelled (specific activity, $85 \mathrm{Ci} / \mathrm{mmole}$ ) and unlabelled R1881 were obtained from The New England Nuclear Corp. (Boston, Mass., U.S.A.) and ${ }^{3} \mathbf{H}$ testosterone (specific activity, $93 \mathrm{Ci} / \mathrm{mmole}$ ) and ${ }^{3} \mathrm{H}$ dihydrotestosterone (specific activity, $175 \mathrm{Ci} / \mathrm{mmole}$ ) were purchased from The Radiochemical Centre (Amersham, England). Unlabelled steroids and ethidium bromide were products of Nakarai Chemical Co. (Kyoto, Japan) and purified by recrystallizations before use. Pure crystals of anabolic steroids were generously supplied by pharmaceutical companies (Bolandiol dipropionate from Dainihon, Nandrone phenylpropionate from Sankyo, Furazabol from Daiichi and Methenolone enanthate from Nippon-Schering) and used without further purification. Other chemicals used were all analytical grade.

Determination of binding capacity of cytosols

Cytosols from ventral prostates were treated with $1 / 4$ volume of dextran-charcoal $(2.5 \%-0.25 \%$ in the buffer) at $0^{\circ} \mathrm{C}$ for $10 \mathrm{~min}$. After brief centrifugation to remove charcoal, an aliquot of the treated cytosols (approximately $2 \mathrm{mg}$ as protein) was incubated with a series concentration of ${ }^{3} \mathbf{H}-\mathrm{R} 1881$ ranging from $0.5 \mathrm{nM}$ to $8 \mathrm{nM}$ in the presence or absence of 500-fold molar excess of unlabelled R1881 in a final volume of $0.4 \mathrm{ml}$ at $0^{\circ} \mathrm{C}$ for $15 \mathrm{hr}$. At the end of the incubation period, unbound steroid was removed with $0.2 \mathrm{ml}$ of the dextran-charcoal, left at $0^{\circ} \mathrm{C}$ for $10 \mathrm{~min}$, centrifuged twice to remove charcoal completely and radioactivity in an aliquot of the supernatant was measured. The radioactivity in the protein-bound fraction which was not displaced by the addition of 500-fold molar excess of unlabelled R1881 was subtracted in all instances. Binding capacity 
(maximum binding sites) was determined by the method of Scatchard (1949).

\section{Analytical methods}

Protein was determined by the method of Lowry et al. (1951). Radioactivity was determined in a Tri-Carb liquid scintillation spectrometer with automatic external standardization for quenching correction.

\section{Results}

Nature of androgen binding in cytosols of the rat ventral prostate

The time courses of the prostatic cytosol from castrated rats to ${ }^{3} \mathrm{H}$-dihydrotestosterone, ${ }^{3} \mathrm{H}$-testosterone and ${ }^{3} \mathrm{H}-\mathrm{R} 1881$ were compared (Fig. 1). Binding increased with time during the incubation period, but the specific bindings reached the maximum plateau by 9 $\mathrm{hr}$ in all cases. The rate of the nonspecific binding to ${ }^{3} \mathrm{H}$-dihydrotestosterone and ${ }^{3} \mathrm{H}$-testosterone was relatively high, therefore it seemed to be unsuitable to use these ligands for androgen receptor determination in the rat ventral prostate. A Scatchard plot of the ${ }^{3} \mathrm{H}-\mathrm{R} 1881$ binding revealed only one high affinity binding component ( $\mathrm{Kd}=1 \mathrm{~nm})$ (Fig. 2). Binding capacity was small in the cytosol obtained from animals which had received testosterone $(30 \mu \mathrm{g} / 100 \mathrm{~g}$ body weitht $)$ at $3 \mathrm{hr}$ before sacrifice, but the binding affinity was almost identical to that of the untreated control (Fig. 2). The binding of ${ }^{3} \mathrm{H}-\mathrm{R} 1881$ was inhibited markedly by the addition of unlabelled dihydrotestosterone, testosterone and R1881 but inhibition by progesterone and estradiol was observed only in concentrations higher than $10^{-8} \mathrm{M}$ (Fig. 3).

Depletion and replenishment of androgen receptor in cytosol after administration of various amounts of testosterone and dihydrotestosterone

Various doses of testosterone $(3-150 \mu \mathrm{g} /$ $100 \mathrm{~g}$ body weight) were administered by a

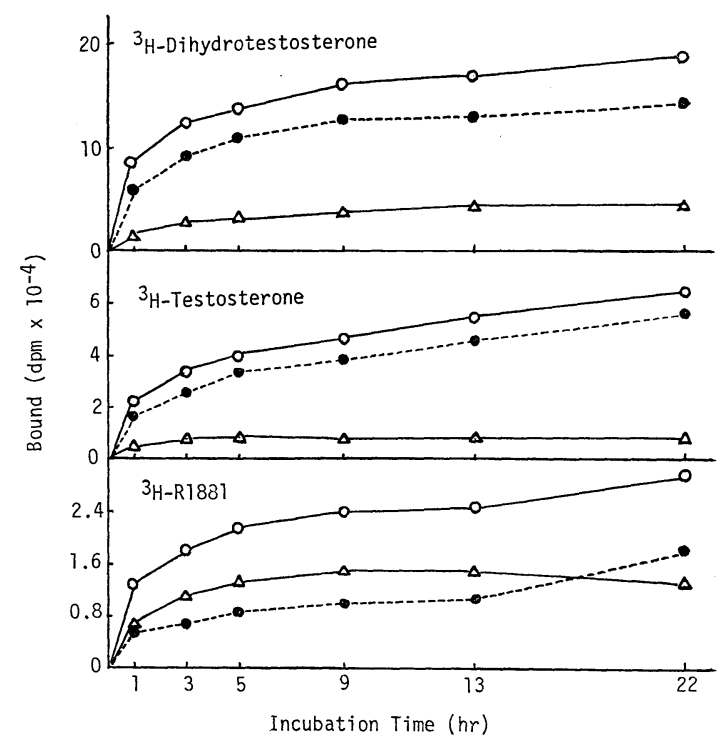

Fig. 1. Time course of binding of ${ }^{3} \mathrm{H}$-dihydrotestosterone, ${ }^{3} \mathrm{H}$-testosterone and ${ }^{3} \mathrm{H}-\mathrm{R} 1881$ in the prostatic cytosol from castrated rats.

The cytosol was prepared from ventral prostates of 8 castrated rats. Aliquots of the cytosol (26 $\mathrm{mg}$ as protein) were incubated either with $10 \mathrm{nM}$ of ${ }^{3} \mathrm{H}$-dihydrotestosterone (specific activity, 175 $\mathrm{Ci} / \mathrm{mmole}$ ), ${ }^{3} \mathrm{H}$-testosterone (specific activity, 93 $\mathrm{Ci} / \mathrm{mmole}$ ) or ${ }^{3} \mathrm{H}-\mathrm{R} 1881$ (specific activity, $87 \mathrm{Ci}$ / mmole) in the presence or absence of 500 -fold molar excess of unlabelled compounds at $0^{\circ} \mathrm{C}$ in a final volume of $2 \mathrm{~m} l$. At various time intervals after the start of incubation, each $0.2 \mathrm{ml}$ was removed and bound radioactivity was determined after removing the unbound steroids with $0.1 \mathrm{ml}$ of dextran-charcoal $(2.5 \%-0.25 \%$ in the buffer). The radioactivity which was not displaced by the addition of 500 -fold molar excess of unlabelled steroid to the incubation mixture was denoted as non-specific binding. Specific binding was calculated by subtracting the non-specific binding from the bound radioactivity observed in the absence of unlabelled steroids.

Bound radioactivity in the absence of unlabelled steroid (a)

- Bound radioactivity in the presence of unlabelled steroid (b)

$\triangle$ Specific binding $(\mathrm{a}-\mathrm{b})$ 


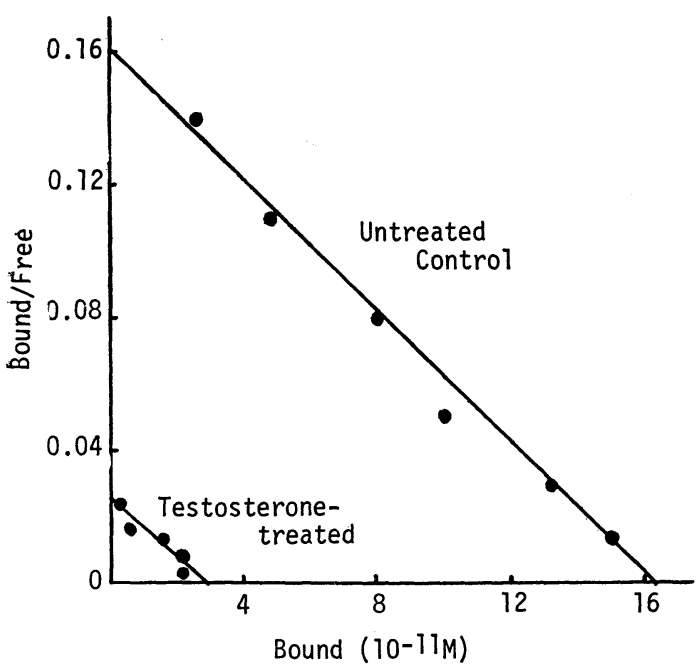

Fig. 2. Scatchard plot of ${ }^{3} \mathrm{H}-\mathrm{R} 1881$ binding in prostatic cytosols from untreated and testosterone treated castrated rats.

Cytosols from untreated controls and from animals at $3 \mathrm{hr}$ after treatment with $30 \mu \mathrm{g}$ testosterone per $100 \mathrm{~g}$ body weight were treated with dextran-charcoal $(2.5 \%-0.25 \%$ in the buffer, $1 / 4$ volume of cytosol) at $0^{\circ} \mathrm{C}$ for $10 \mathrm{~min}$. After brief centrifugation, cytosols $(2.6 \mathrm{mg}$ and $2.2 \mathrm{mg}$ as protein in control and in testosterone treated) were incubated with a series concentration of ${ }^{3} \mathrm{H}-\mathrm{R} 1881$ ranging from $0.25 \mathrm{nM}$ to $8 \mathrm{nM}$ in the presence or absence of 500 -fold molar excess of unlabelled $\mathrm{R} 1881$ in a final volume of $0.4 \mathrm{ml}$ at $0^{\circ} \mathrm{C}$ for $10 \mathrm{hr}$. After incubation, unbound steroids were removed with $0.2 \mathrm{ml}$ of the dextran-charcoal, centrifuged at $3,000 \times g$ for $5 \mathrm{~min}$ twice and radioactivity in an aliquot of the supernatant was determined. Results were corrected for the non-specific binding which was not displaced by addition of a 500 -fold molar excess of unlabelled R1881. $\mathrm{K}_{\mathrm{d}}$ obtained from the Fig. was approximately $1 \mathrm{nM}$ in both cytosols and maximum binding sites were 63 and $13 \mathrm{fmoles} / \mathrm{mg}$ protein of cytosol for the control and for the testosterone treated, respectively.

single subcutaneous injection to castrated rats and changes in the binding capacity of prostatic cytosols were determined at various time intervals following injection. The testosterone injection resulted in a rapid decline in the binding capacity from about 50 to 10 fmoles per $\mathrm{mg}$ protein, except that in the animals which received only 3 $\mu \mathrm{g}$, where only half the level of depletion was observed (Fig. 4). The binding capacity reached the minimum level within the first $1 \mathrm{hr}$ and then showed a tendency to return to the control level. Approximately 20\% of the binding was resistant to testosterone administration and even after a larger injection of testosterone, this fraction of the binding was still observed. The time of onset of replenishment of the receptor in the cytosol seemed to be dependent on the dose administered; in the cytosol from animals treated with 10 and $30 \mu \mathrm{g}$, the binding reappeared at $6 \mathrm{hr}$ after injection, but in cytosols of 50 and $150 \mu \mathrm{g}$ treated animals, the replenishment was not observed at $11 \mathrm{hr}$ and in the latter case, the binding

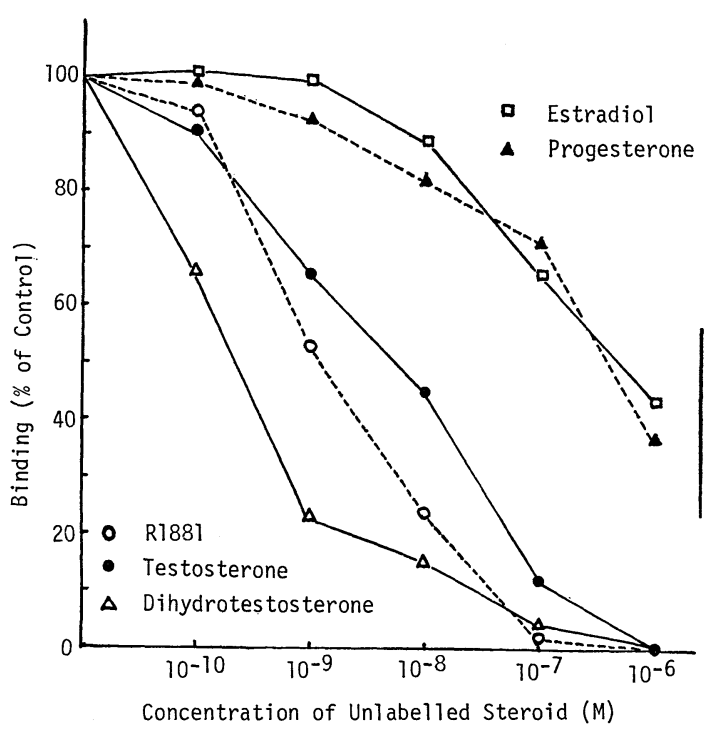

Fig. 3. In vitro inhibition by various steroids of ${ }^{3} \mathrm{H}-\mathrm{R} 1881$ binding in prostatic cytosol.

Duplicate aliquots of the prostatic cytosol obtained from 7 castrated rats $(2.2 \mathrm{mg}$ as protein) were incubated with $4 \mathrm{nM}{ }^{3} \mathrm{H}-\mathrm{R} 1881$ in the presence of a series concentration $\left(0-10^{-6} \mathrm{M}\right)$ of various unlabelled steroids under the routine binding assay conditions. Non-specific binding, defined as that binding not displaced by the addition of 500fold molar excess of R1881, was subtracted in all instances. Results are expressed as \% of the control $(26,400 \mathrm{dpm}$, average of duplicate). 
capacity was still less than $1 / 3$ that of the uninjected control even at $30 \mathrm{hr}$ postinjection.

The administration of dihydrotestosterone (10-50 $\mu \mathrm{g} / 100 \mathrm{~g}$ body weight) evoked a similar change in the binding capacity but the replenishment started earlier than in testosterone-treated animals; the binding increased at $6 \mathrm{hr}$ and returned almost to the contrel level at $20 \mathrm{hr}$ after injection even in the $50 \mu$ g-treated animals (Fig. 5).

Testosterone propionate was dissolved in cotton seed oil and administered subcutaneously to castrated rats $(10 \mathrm{mg}$ in $0.2 \mathrm{mll}$ head). Changes in the binding capacity of cytosol were followed in these animals (Fig. 6). The low level of the receptor in the cytosol persisted for a week after injection and replenishment was observed at the 9 th day postinjection. A reciprocal relationship was observed between the binding capacity and the protein concentration in the cytosols; during the period of receptor depletion the concentration of protein began to increase and showed a tendency to decrease along with the onset of the replenish-

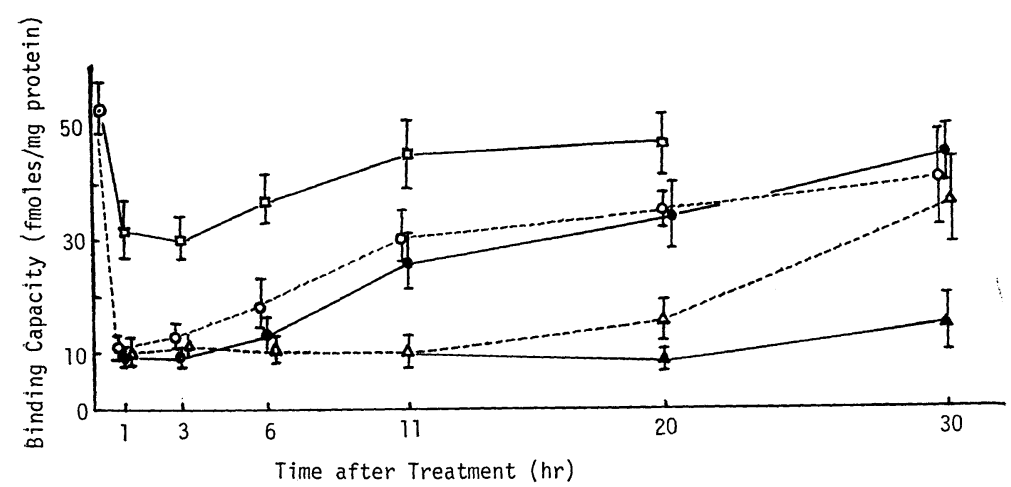

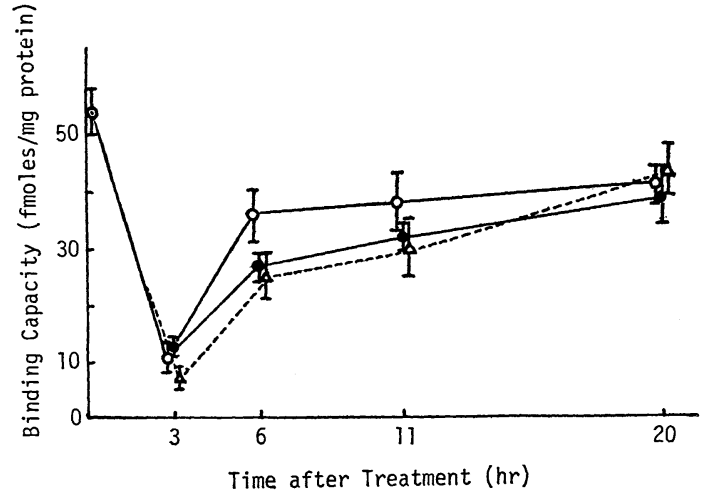

Fig. 5. Depletion and replenishment of androgen receptor in prostatic cytosols after administration of various amounts of dihydrotestosterone.

Various amounts $(10,30$ and $50 \mu \mathrm{g} / 100 \mathrm{~g}$ body weight) of dihydrotestosterone were dissolved in $0.3 \mathrm{ml}$ of $30 \%$ ethanol-saline solution and administered to castrated rats subcutaneously. Other experimental conditions were the same as described in the legend to Fig. 3. Doses of dihydrotestosterone administered were : $\circ 10 \mu \mathrm{g}, \bullet 30 \mu \mathrm{g}$ and $\Delta 50 \mu \mathrm{g}$ per $100 \mathrm{~g}$ body weight, respectively.

Fig. 4. Depletion and replenishment of androgen receptor in prostatic cytosols after administration of various amounts of testosterone.

Various amounts $(3,10$, 30,50 and $150 \mu \mathrm{g} / 100 \mathrm{~g}$ body weight) of testosterone in $0.3 \mathrm{ml}$ of $30 \%$ ethanol-saline solution were injected to castrated animals subcutaneously and the binding capacity of the prostatic cytosol to ${ }^{3} \mathrm{H}-\mathrm{R} 1881$ was determined at various time intervals after injection. Each point is expressed as a mean binding capacity (fmoles/mg protein) \pm standard error in 3 to 6 experiments performed independently. Doses of testosterone administered were: $\square 3 \mu \mathrm{g}, \quad \circ 10 \mu \mathrm{g}$, - $30 \mu \mathrm{g}, \Delta 50 \mu \mathrm{g}$ and $\Delta$ $150 \mu \mathrm{g}$ per $100 \mathrm{~g}$ body weight, respectively. 


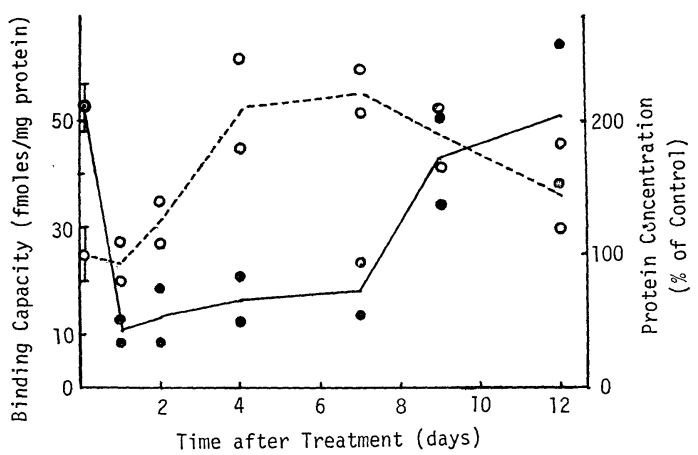

Fig. 6. Depletion and replenishment of androgen receptor and changes in concentration of cytosol protein after administration of oil-dissolved testosterone propinate.

Testosterone propinate was dissolved in cotton seed oil $(10 \mathrm{mg} / 0.2 \mathrm{ml})$ and injected to castrated rats subcutaneously. At various times after injection, the binding capacity to ${ }^{3} \mathrm{H}-\mathrm{R} 1881$ and protein concentration in the prostatic cytosols were determined. Two rats were used for each assay. The protein concentration was expressed as percent of that of the untreated control. The protein concentration in cytosols of untreated control was $10.15 \pm 0.45 \mathrm{mg} / \mathrm{ml}$ (mean \pm standard error in 17 determinations) when tissues from two rats were homogenized with $2.5 \mathrm{ml}$ of the buffer solution.

ment of the receptor. In this experiment, the binding capacity was expressed based on the concentration of protein in the cytosol, and the concentration of protein in the cytosol increased approximately 2-fold during the period of receptor depletion. The decrease in the binding of the gland during this period was less remarkable when the binding was corrected for the increase in the protein concentration. However, the binding observed in this period might be attributed mainly to the "resistant fraction" of the binding to testosterone injection (see Fig. 4). For this reason, the concentration of the receptor which is "sensitive" to testosterone treatment in the gland in this period seems to be a significantly depleted amount.
Effect of progesterone, cyproterone acetate and ethidium bromide on receptor depletion induced by testosterone administration

The administration of progesterone and cyproterone acetate neither caused any depletion of the recepter nor influenced the depletion induced by the administration of testosterone even in relatively high doses (200 $\mu \mathrm{g} / 100 \mathrm{~g}$ body weight) (Table 1$)$. The inhibition by cyproterone acetate of the binding of androgen receptor was reported (Krieg et al., 1977, Kodama et al., 1978, Menon et al., 1978). The results observed in this experiment may possibly be explained by the fact that injected cyproterone acetate is bound to the androgen receptor in the ventral prostate but the cyproterone acetatereceptor complex is not translocated to the nuclei and stays in the cytoplasm. This possibility was examined during incnbation where cytosol was preincubated with unlabelled cyproterone acetate $(1 \mu \mathrm{M})$ or R1881 $(20 \mathrm{~nm})$ at $0^{\circ} \mathrm{C}$ for $5 \mathrm{hr}$, unbound steroids were removed by dextran-charcoal and these preincubated cytosols were further incubated with ${ }^{3} \mathrm{H}-\mathrm{R} 1881$ (6 $\mathrm{nm}$ ) in the presence or absence of 500-fold molar excess of unlabelled $\mathrm{R} 1881$ at $0^{\circ} \mathrm{C}$ for various time intervals. The rate of the exchange between unlabelled R1881 bound to the cytosol and ${ }^{3} \mathrm{H}-\mathrm{R} 1881$ was relatively low, while an almost complete exchange of cyproterone acetate was achieved at $10 \mathrm{hr}$ of incubation (Fig. 7). These observations seem to support the possibility mentioned above. Ethidium bromide inhibited the in vitro nuclear binding of steroid hormonereceptor complexes (Andre et al., 1977, Izawa and Ichii, 1980), but concomitant administ ration of this dye with testosterone did not evoke any alteration in the receptor depletion induced by testosterone (Table 1).

\section{Effect of anabolic steroids on the binding} capacity of the prostatic cytosol

The in vivo and in vitro effect of 4 anabolic steroids, 2 19-nor-(Bolandiol dipro- 
Table 1. Effect of progesterone, cyproterone acetate and ethidium bromide on the depletion of cytoplasmic R1881 binding induced by testosterone administration.

\begin{tabular}{|c|c|c|}
\hline \multirow{2}{*}{ Treatment of Animals } & \multicolumn{2}{|c|}{ Time after Treatment } \\
\hline & $3 \mathrm{hr}$ & $6 \mathrm{hr}$ \\
\hline Control & $53.4+3.0$ fmoles $/ \mathrm{mg}$ protein $(27)$ & \\
\hline Progesterone $(50 \mu \mathrm{g})$ & $41.8 \pm 4.6(3)$ & \\
\hline$(100 \mu \mathrm{g})$ & $45.2 \pm 5.3$ & \\
\hline$(200 \mu \mathrm{g})$ & $35.9 \pm 5.5(3)$ & $43.1 \pm 4.4(3)$ \\
\hline \multicolumn{3}{|l|}{ Progesterone $(200 \mu \mathrm{g})$} \\
\hline +Testosterone $(30 \mu \mathrm{g})$ & $13.6 \pm 2.6(6)$ & $14.1 \pm 3.3$ \\
\hline Cyproterone acetate $(200 \mu \mathrm{g})$ & $56.4 \pm 5.8$ & $60.0(1)$ \\
\hline$(400 \mu \mathrm{g})$ & $47.5(1)$ & $50.4(1)$ \\
\hline \multicolumn{3}{|l|}{ Cyproterone acetate $(200 \mu \mathrm{g})$} \\
\hline+ Testosterone $(10 \mu \mathrm{g})$ & $17.8 \pm 3.3(3)$ & \\
\hline+ Testosterone $(50 \mu \mathrm{g})$ & $11.9 \pm 2.6(3)$ & \\
\hline Ethidium bromide $(2.4 \mathrm{mg})$ & $52.3 \pm 4.8(3)$ & \\
\hline \multicolumn{3}{|l|}{ Ethidium bromide $(2.4 \mathrm{mg})$} \\
\hline+ Testosterone $(10 \mu \mathrm{g})$ & $11.4 \pm 1.3(3)$ & $20.8 \pm 4.3(3)$ \\
\hline+ Testosterone $(30 \mu \mathrm{g})$ & $17.6 \pm 3.9(3)$ & \\
\hline+ Testosterone $(50 \mu \mathrm{g})$ & $16.9(1)$ & $13.2 \pm 2.3(3)$ \\
\hline
\end{tabular}

Dose of compounds used for treatment of animals is expressed as per $100 \mathrm{~g}$ of body weight.

Results are expressed as mean \pm standard error (number of experiments performed).

For details of the experimental conditions, see the Materials and Methods.

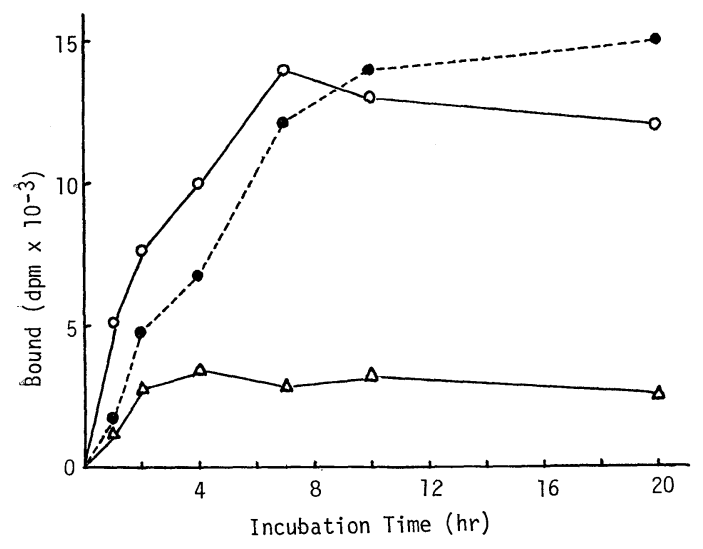

Fig. 7. Binding of ${ }^{3} \mathrm{H}-\mathrm{R} 1881$ in prostatic cytosols preincubated with cyproterone acetate or unlabelled R1881.

Cytosol was prepared from ventral prostates of 8 castrated rats and divided into 3 parts. Each part of the cytosol was incubated in the presence of the buffer (control), $1 \mu \mathrm{M}$ cyproterone acetate or $20 \mathrm{nM}$ unlabelled $\mathrm{R} 1881$ at $0^{\circ} \mathrm{C}$ for $5 \mathrm{hr}$. At the end of incubation period, the incubation mixture was treated with dextran-charcoal $(2.5 \%-$ $0.25 \%, 1 / 3$ volume of the incubation mixture, precipitated by centrifugation prior to addition) at $0^{\circ} \mathrm{C}$ for $10 \mathrm{~min}$. The incubated cytosol was further incubated with $6 \mathrm{nM}{ }^{3} \mathrm{H}-\mathrm{R} 1881$ in the presence or absence of 500 -fold molar excess of unlabelled R1881. At various time intervals after the start of incubation, each $0.2 \mathrm{ml}$ was taken, treated with $0.1 \mathrm{~m} l$ of dextran-charcoal at $0^{\circ} \mathrm{C}$ for $10 \mathrm{~min}$, centrifuged twice and the radioactivity in the supernatant was determined. Non-specifically bound radioactivity was subtracted in all instances. o control. preincubated in the presence of cyproterone acetate or $\Delta$ unlabelled R1881. 


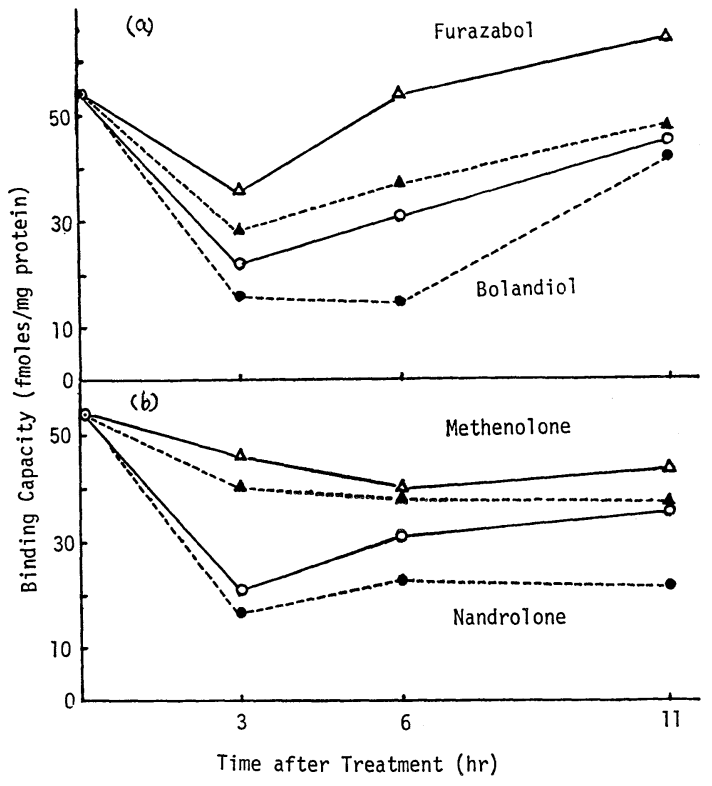

Fig. 8. Depletion and replenishment of androgen receptor in prostatic cytosols of castrated rats after administration of anabolic steroids.

Anabolic steroids were finely suspended in 0.3 $\mathrm{ml}$ of $30 \%$ ethanol-saline solution with the aid of a glass homogenizer and injected subcutaneously immediately after preparation. Binding capacity of the prostatic cytosol to ${ }^{3} \mathrm{H}-\mathrm{R} 1881$ was determined at various time intervals after injection. a) Bolandiol dipropionate, $\Delta$ Furazabol. b) $\circ$ Nandrolone phenylpropionate, $\Delta$ Methenolone acetate. In both Figs., empty and solid symbols denote the administered dose of 30 and $100 \mu \mathrm{g}$ per $100 \mathrm{~g}$ body weight, respectively. A point in the Fig. is the average for 3 experiments performed independently.

pionate and Nandrolone phenylpropionate) and 2 methyl-derivatives (Furazabol and Methenolone enanthate) of androstene, on the binding of ${ }^{3} \mathrm{H}-\mathrm{R} 1881$ was examined (Figs. 8 and 9). A higher degree of depletion of the receptor binding was observed in animals treated with 19-nor-compounds and the effect of the administration of methyl-derivatives was relatively small. Replenishment took place at $11 \mathrm{hr}$ after injection even with $100 \mu \mathrm{g}$ per $100 \mathrm{~g}$ body weight, except that rate of the replenishment in animals which received $100 \mu \mathrm{g}$ of

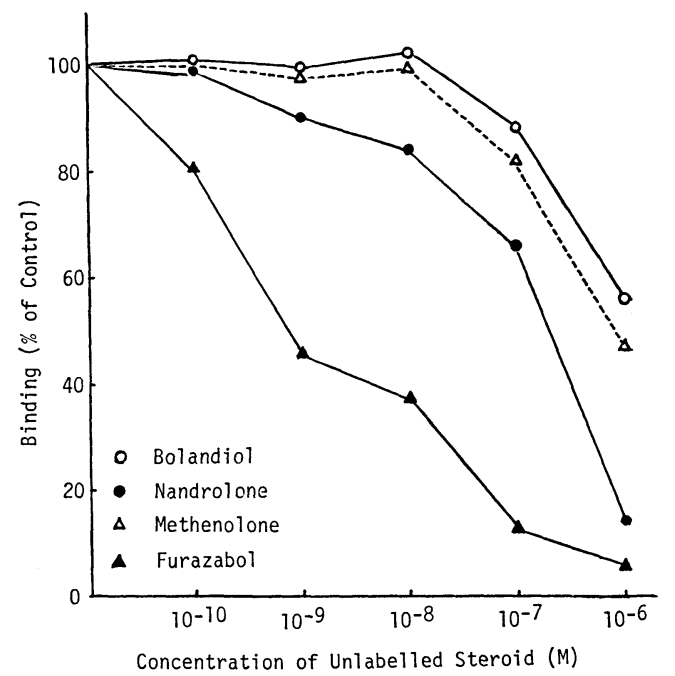

Fig. 9. In vitro inhibition by various anabolic steroids of $3 \mathrm{H}-\mathrm{R} 1881$ binding in prostatic cytosol.

Prostatic cytosol from 7 castrated rats $(2.5 \mathrm{mg}$ as protein/tube) was used. Other experimental conditions were the same as those described in the legend to Fig. 3. The control binding was $38,000 \mathrm{dpm}$ (average of duplicate).

Nandrolone was low. The rate of in vitro inhibition of ${ }^{3} \mathrm{H}-\mathrm{R} 1881$ binding by these anabolic steroids did not correlate with the potential for depletion of the receptor in vivo. Inhibition by Bolandiol and Methenolone was slight, moderate by Nandrolone but inhibition by Furazabol was profound; the potency of inhibition being almost comparable to that of testosterone or R1881.

\section{Discussion}

R1881 has been known to bind to androgen as well as progesterone receptors (Menon et al., 1978, Dube et al., 1979). In the present study, ${ }^{3} \mathrm{H}-\mathrm{R} 1881$ was used for the assessment of androgen receptor in the ventral prostate of rats. However, it was observed in the study of in vitro inhibition of ${ }^{3} \mathrm{H}-\mathrm{R} 1881$ binding in the prostatic cytosol that the rate of inhibition of 
binding by progesterone was quite low even in the range of high concentrations (Fig. 3). The contribution of the progesterone binder to the binding assay of androgen receptor in rat prostate therefore seemed to be insignificant under the experimental conditions used in the present study.

Administration of testosterone to castrated rats resulted in a rapid decrease in the binding capacity of prostatic cytosols to ${ }^{3} \mathrm{H}$ $\mathrm{R} 1881$. The reduction is not attributable to the presence of unlabelled testosterone in cytosols of the treated animals, since cytosols were treated with dextran-charcoal before incubation with ${ }^{3} \mathrm{H}-\mathrm{R} 1881$ and the Scatchard plot analysis revealed similar $\mathrm{Kd}$ values in the control and testosterone treated animals (Fig. 2). The rate of reduction of the binding at $1 \mathrm{hr}$ postinjection was about $40 \%$ and $80 \%$ in rats which had received $3 \mu \mathrm{g}$ and higher than $10 \mu \mathrm{g}$ per $100 \mathrm{~g}$ body weight, respectively. The rate of inhibition was not increased when animals were treated with higher doses. The nature and physiological significance of the binder which is resistant to high doses of testosterone administration is not yet clear. The low level of binding in the cytosols persisted for some intervals after administration and then the binding capacity of the cytosols was restored (Fig. 4). The length of the depleted periods seemed to be dependent on the doses of testosterone administered. Concerning mechanisms of the receptor replenishment after depletion induced by steroid hormone administration, Ishii et al., (1972) stated that recycling of translocated receptors to the cytoplasm plays an important role, while Korach and Ford (1978) and Jungblut et al. attributed the receptor replenishment to a new synthesis of receptor protein. The observation that the time of onset of the replenishment was correlated to doses administered suggested that the recycling or synthesis of receptors, if any, is possibly regulated by intracellular steroids. Actually in a separate experiment performed in this laboratory, it was observed that glucocorticoid receptor depleted after the administration of dexamethasone in the cytosol of rat liver reappeared when the intracellular concentration of dexamethasone dropped to an insignificantly low level (report to be published elsewhere). The replenishment took place earlier when dihydrotestosterone was administered (Fig. 5) and this might be attributable to the shorter intracellular halflife of this androgen.

The administration of a large amount of testosterone propionate dissolved in oil evoked depletion of the binding for more than a week. The protein concentration in the cytosol was increased during the depleted period and showed a tendency to decrease when the binding was relenished (Fig. 6). This indicated that the depletion of the cytoplasmic receptor is clearly correlated to the biological action of androgen.

Progesterone and cyproterone acetate have been known as antiandrogens. The injection of these agents neither caused any changes in the binding capacity nor influenced the depletion induced by testosterone. The inhibition by cyproterone acetate of the formation of dihydrotestosterone-receptor complex in the nuclei of rat ventral prostate was reported (Fang et al., 1969) and the results obtained in in vivo and in vitro experiments in the present study (Fig. 6 and Table 1) suggested that the cyproterone acetate-receptor complex was not transferred to nuclei but stayed in the cytoplasm. This might be an essential feature of the antiandrogenic action of these agents.

Ethidium bromide inhibited in vitro nuclear binding of steroid hormone-receptor complexes (Ander et al., 1977, Izawa and Ichii, 1980) and it was therefore expected that pretreatment of animals with this intercalating dye would influence the depletion of cytoplasmic binding. However, no significant effect of the treatment was observed (Table 1). Two classes of binding sites for steroid hormone-rectepor complexes 
were observed in the nuclei; one was sensitive and the other was resistant to ethidium bromide (Izawa and Ichii, 1980) and the fact that ethidium bromide failed to affect depletion seems to indicate that the ethidium bromide sensitive sites in nuclei are less biologically significant, if one assumes that a sufficient concentration of ethidium bromide administered intraperitoneally was distributed in the ventral prostate. Actually, the binding affinity of the steroid hormone-receptor complex to the ethidium bromide sensitive sites was low (Izawa and Ichii, 1980) and prior injection of ethidium bromide did not show any modifications in tyrosine aminotransferase induction evoked by dexamethasone injection (Ichii, unpublished observation).

Effect of four steroidal compounds which have been used clinically as anabolic steroid on the binding capacity of prostatic cytosols was examined. All of them depleted the cytoplasmic androgen receptor but the degree of depletion was much lower than that evoked by testosterone. Generally, nortestosterone derivatives exhibited more potency causing depletion than methyltestosterone derivatives. At the same time, it might be worth mentioning that the inhibitory action of these compounds on the in vitro binding of ${ }^{3} \mathrm{H}-\mathrm{R} 1881$ was completely different from the potency in causing depletion in vivo (Fig. 9). Furazabol showed a marked inhibition in vitro, which was almost comparable to those of testosterone and R1881. The reason of these discrepancies observed in vivo and in vitro is not clear at the present time but it is apparent that the rate of inhibition of the in vitro binding is not a proper index of biological potency in vivo. The examination of the effect of these anabolic steroids on the binding capacity to ${ }^{3} \mathrm{H}-\mathrm{R} 1881$ in muscles was another aim of the present study. High affinity androgen receptors have been reported in the levator ani as well as the skeletal muscles of rats (Jung and Baulieu,
1972, Tremblay et al., 1977, Gustafsson and Poussette, 1975). However, in our study, it was almost impossible to facilitate an accurate binding assay in muscle even by using a relatively high concentration of tissue, since the level of the high affinity binding to ${ }^{3} \mathrm{H}-\mathrm{R} 1881$ was extremely low.

In conclusion, deletion and replenishment of the cytoplasmic androgen receptor was dependent on the dose and the biological potency of steroids used for the treatment of animals and this may imply that the cytoplamic receptor is regulated by the presence of hormones in the cytoplasm and also possibly in the nucleus and the depletion of the cytoplasmic receptor seemed to be closely related to the biological action of androgens. This kind of study may provide a fundamental rationale for the regimen and time schedule of administration in steroid hormone therapy in addition to throwing light on the action mechanism of steroid hormones.

\section{Acknowledgements}

The author is indebted to pharmaceutical companies, the Daiichi, Nippon-Schering, Dainihon and Sankyô for their generous supply of pure crystalls of anabolic steroids. This work was supported in part by Grants-in-Aid for Scientific Research from the Ministry of Education, Science and Culture, Japan.

\section{References}

Andre, J., P. Vic, C. Humeau and H. Rochefort (1977). Mol. Cell. Endocrinol. 8, 225.

Batra, S. (1979). J. Steroid Biochem. 11, 407.

Baudendistel, L. J., M. F. Ruh, E. M. Nadel and T. S. Ruh (1978). Acta Endocrinol. 89, 599.

Cildowsky, J. A. and T. G. Muldoon (1976). Biol. Reprod. 15, 381.

Clark, J. H., J. N. Anderson and E. J. Peck (1973). Steroids 22, 707.

Duke, J. Y., R. Lesage and R. R. Tremblay (1973). J. Steroid Biochem. 10, 459.

Fang, S., K. M. Anderson and S. Liao (1969). $J$. Biol. Chem. 244, 6584. 
Gustafsson, J. A. and A. Pousette (1975). Biochemistry 14, 3094.

Horwitz, K. B. and W. L. McGuire (1978). J. Biol. Chem. 253, 8185.

Ishii, D. N., W. R. Pratt and L. Aronow (1972). Biochemistry 11, 3896.

Isomaa, V., H. Isotalo, M. Orava and O. Janne (1979). Biochim. Biophys. acta 585, 24.

Izawa, M. and S. Ichii (1980). Endocrinol. Japon. 27, 101.

Jung, I. and E. E. Baulieu (1972). Nature 237, 24.

Jungblut P. W., E. Kallweit, W. Sierralta, A. J. Truitt and R. K. Wagner (1978). Hoppe-Zeyler's Z. Physiol. Chem. 359, 1259.

Jungblut, P. W., A. Hughes, J. Gaues, E. Kallweit, I. Maschler, F. Parl, W. Sierralta, P. Szendro and R. K. Wagner (1979). J. Steroid Biochem. 11, 273.

Kazenellenbogen, B. S. and E. R. Ferguson (1975). Endocrinology 79, 1.

Kodama, T., S. Honda and J. Shimazaki (1978). Endocrinol. Japon 25, 453.

Koseki, Y., D. T. Zava, G. C. Chamness and W. L. McGuire (1977). Endocrinology 101, 1104.
Korach, K. S., and E. B. Ford (1978). Biochem. Biophys. Res. Commun. 83, 327.

Krieg, M., W. Bartsch, S. Herzer, H. Becker and K. D. Voigt (1977). Acta Endocrinol. 86, 200.

Lowry, O. H., N. Rosebrough, A. L. Farr and R. J. Randall (1955). J. Biol. Chem. 193, 265.

Luu Tai, M., E. E. Baulieu and E. Milgrom (1975). J. Endocrinol. 66, 349.

Menon, M., C. E. Tananis, L. L. Hicks, E. E. Hawkins, M. G. McLoughlin, and P. C. Walsh (1978). J. Clin. Invest. 61, 150.

Mester, J. and E. E. Baulieu (1975). Biochem. J. 146, 617.

Mester, J. and E. E. Baulieu (1977). Eur. J. Biochem. $72,405$.

Panko, W. B. and R. M. MacLeod (1978). Cancer Res, 38, 1948.

Scatchard, T. (1949). Ann. N.Y. Acad. Sci. 51, 660. Tremblay, R. R., J. Y. Dube, M. A. Ho-Kim and R. Lesage (1977). Steroids 29, 185.

Van Doorn, E. and N. Bruchovsky (1978). Biochem. J. 174, 9. 